\title{
BREVE PERCURSO HISTÓRICO DE ABORDAGENS LINGUÍSTICAS QUE ANTECEDEM E INFLUENCIAM A CONSTITUICCÃO DA SOCIOLINGUIISTICA VARIACIONISTA
}

\author{
BRIEF HISTORICAL ROUTE OF LINGUISTICS APPROACHES \\ THAT PRECEDES AND INFLUENCES THE VARIATIONIST \\ SOCIOLINGUISTICS' CONSTITUTION
}

Marcela Langa LACERDA ${ }^{1}$

Resumo: Este artigo objetiva resgatar uma parte da história dos estudos linguísticos que antecedem e influenciam a constituição da Sociolinguística Variacionista. Para isso, retoma brevemente a história da Linguística dos séculos XVIII ao XX, considerando fatos que interessam ao tema variação e mudança linguística, no âmbito das seguintes abordagens: (i) os estudos comparados, (ii) os histórico-comparados, (iii) os neogramáticos, (iv) os dialetológicos, (v) o estruturalismo; e (vi) o gerativismo. As ideias de Humboldt e Whitney e de Meillet e Martinet também são consideradas. Esta revisão permitiu, além da (i) sistematização de uma versão sobre as influências históricas que constituem a Sociolinguística Variacionista, identificada como uma metateoria estrutural, (ii) apontamentos sobre algumas tarefas atuais dos variacionistas, dada a guinada discursiva do campo, por meio de sua terceira fase, identificada agora com uma metateoria discursiva.

Palavras-chave: Sociolinguística Variacionista. Influências históricas. Abordagem estrutural.
Abstract: The following article aims to resume a historical part of linguistic studies that precedes and influences the constitution of Variationist Sociolinguistics. For this reason, there is a brief resume about Linguistics' history through the 18th to 20th centuries, considering facts that matter to subjects as variation and linguistic change, within the scope of the following approaches of (i) the comparatives studies, (ii) the historical-comparative, (iii) the neogrammarians, (iv) the dialectologists, (v) structuralism; and (vi) gerativism. Humboldt and Whitney's and Meillet and Martinet's ideas are also considered. This inspection allowed, besides the (i) systematization of a version about the historical influences that constitute the Variationist Sociolinguistics, identified as a structural metatheory, (ii) notations about some variationists' recent tasks, based on the sudden discursive change of the field, through its third phase, identified now as a discursive metatheory.

Keywords: Variationist Sociolinguistics. Historical influences. Structural approach.

1 Universidade Federal do Espírito Santo (UFES), Vitória, Espírito Santo, Brasil; marcelalanga@yahoo.com.br; https://orcid.org/0000-0002-8824-8339 
- Breve percurso histórico de abordagens linguísticas que antecedem e influenciam a constituição da sociolinguística variacionista

\section{Introdução}

Conhecer a prática científica ${ }^{2}$ de pesquisadores de uma dada abordagem significa conhecer a teia que amarra seus recortes, métodos e sistemas argumentativos, bem como conhecer a própria história de constituição da abordagem (FARACO, 2005), tendo em vista que todo fazer científico "se alimenta do próprio passado, e o estágio que atinge numa dada época serve de ponto de partida para as investigações posteriores" (ROBINS, 1983, p. 3).

Além disso, subjacente a cada abordagem ou prática científica - enquanto prática sócio-histórica muito bem delimitada no tempo e no espaço - há sempre um quadro de restrições epistemológicas ou metateóricas (compreendidas em termos ideológicos ou de visão de mundo (FIGUEROA, 1994) a partir do qual o fazer científico se configura. Por isso, sempre há, no fazer científico, a coexistência de diferentes explicações ou hipóteses interpretativas para um mesmo evento; e assumir determinados sistemas argumentativos implica admitir seus pressupostos, ainda que tacitamente.

Disso decorre que o fazer científico envolve sempre uma tomada de posição quanto à delimitação, por exemplo, do próprio objeto de estudo, determinando o que lhe é próprio e o que lhe é exterior. Produz-se, com isso, resíduos ou aspectos que, deixados à parte, só podem ser recuperados por outros pontos de observação, instaurados no interior da mesma abordagem ou a partir de novas, que emergem como reação às abordagens anteriores. Desse modo, é, pois, a própria natureza ideológica da prática científica que sustenta seu estado provisório e garante um movimento contínuo na história da ciência (GERALDI, 1990).

Considerando a história da Linguística, em particular, as diferentes abordagens que a constituem não devem ser compreendidas em termos de avanços lineares, isto é, em termos de acúmulo de conhecimento ao longo do tempo que promove modificações na área, mas em termos de rupturas, de conflitos ideológicos entre os pesquisadores, ao mesmo tempo em que devem ser vistas também em termos de continuidade, dado que influências e pontos de interesse podem se manter, ao longo da história, embora vistos, esses últimos, de maneira renovada, mediante a constituição de novas bases epistemológicas.

Este é o caso do tratamento dos temas variação e mudança linguística, pois, embora presentes em diferentes abordagens, receberam diversas e reversas explicações, por

2 Uso, neste texto, os termos prática de pesquisa, abordagem e campo (investigativo) alternadamente. 
conta de mudanças no próprio clima intelectual de cada período; compreender cada uma delas implica distinguir os pressupostos subjacentes a cada teoria, tarefa que melhor se efetiva quando se conhece a história do pensamento filosófico-linguístico, "fundo para uma melhor compreensão do estabelecimento" (KOERNER, 2014, p. 124) de linhas investigativas específicas.

Em vista disso, este artigo objetiva resgatar uma parte da história dos estudos linguísticos que antecedem e influenciam, paradoxalmente, a constituição da Sociolinguística Variacionista (doravante SV), campo que primeiramente se dedica à investigação da variação, com vistas à explicação da mudança linguística. Com isso, espera-se lançar luz não apenas sobre o movimento histórico que enseja a emergência da SV, mas também sobre as bases epistemológicas constituídas para balizar essa prática investigativa.

Em nossa compreensão,

[...] os pesquisadores precisam desenvolver uma consciência dos pressupostos subjacentes à prática em seus campos, para que eles possam, se necessário ou apropriado, consultar de forma coerente essas suposições. Eles também precisam desenvolver uma consciência contínua das relações entre os seus próprios campos e outros - e dos antecedentes históricos que constituíram seu campo - às vezes, fornecendo um quadro contra o qual os profissionais reagem. (MILROY; GORDON, 2003, p. 1).

O texto retoma brevemente a história da Linguística dos séculos XVIII ao XX, considerando os fatos que interessam ao tema variação e mudança linguística. A exposição organiza-se em torno de uma periodização histórica por séculos - procedimento que, embora seja arbitrário, pode ter algum valor mnemônico (ROBINS, 1983).

Voltando-se especialmente para estudantes de graduação do curso de Letras que iniciam os estudos em Sociolinguística Variacionista, esta exposição está organizada em três seções: na primeira, retomam-se estudos que se localizam entre o final do século XVIII e início do XX; na segunda seção, retomam-se estudos marcantes do século XX; na terceira seção, destinada às considerações finais, sistematiza-se o breve escorço histórico, remetendo o leitor às diferentes influências que constituem a SV, na década de 1960. Como apontamos brevemente nas considerações finais, a emergência de uma terceira fase (/onda) sociolinguística (ECKERT, 2012) parece ser precisamente uma reação a essas influências, radicalizadas ao longo de quase 60 anos de trabalho. 
- Breve percurso histórico de abordagens linguísticas que antecedem e influenciam a constituição da sociolinguística variacionista

\section{Os primeiros estudos da linguística moderna: do século XVIII ao XIX}

Embora a reflexão sobre a linguagem seja milenar, é no fim do século XVIII que se encontram bases mais sólidas para o advento da Linguística enquanto ciência, tendo em vista, principalmente, o desenvolvimento das seguintes abordagens: (i) os estudos comparados, (ii) os histórico-comparados, (iii) os neogramáticos, e (iv) os dialetológicos. Confere-se ainda destaque, nesta seção, às ideias de Humboldt e Whitney, não localizadas especificamente em nenhuma dessas abordagens, mas cruciais para o pensamento linguístico moderno.

\section{Os estudos comparados}

O desenvolvimento da Linguística Comparada decorreu, em primeiro lugar, do interesse crescente de um grupo de intelectuais europeus, principalmente William Jones (1746-1794), pelo estudo do sânscrito, língua clássica dos hindus, e, em segundo lugar, da descoberta de que as línguas poderiam ser comparadas entre si, a partir da percepção de que havia uma relação entre o sânscrito e as línguas modernas, como grego e latim.

O candente interesse pelo sânscrito inscreve-se no próprio contexto ideológico do movimento filosófico, artístico e político que marcou o fim do século XVIII e se manteve ao longo do século XIX: o Romantismo, que, tendo como uma de suas máximas a nostalgia do passado remoto, visto como tempo áureo em relação a uma contemporaneidade degradada, fez renascer o pressuposto de que línguas mais antigas seriam mais complexas do que as contemporâneas. Com isso, "reconstrução das línguas primitivas (antigo germânico, antigo eslavo, indo-europeu) mediante a investigação sistemática de documentos do passado, tornou-se um meio de conhecimento da pré-história de seus falantes e de culturas ancestrais" (CAMACHO, 2013, p. 87).

A crença de que uma língua antiga teria dado origem a novas línguas orientou fortemente o trabalho de comparar e classificar as línguas por meio do método comparativo, que presume que "entre elementos de línguas aparentadas existem correspondências sistemáticas (e não apenas aleatórias ou casuais) em termos de estrutura gramatical, correspondências estas passíveis de serem estabelecidas por meio duma cuidadosa comparação" (FARACO, 2005, p. 134). As línguas europeias seriam, assim, uma transformação natural da língua-mãe ou indo-europeu (língua pré-histórica hipotética).

Franz Bopp (1791-1867), um dos primeiros comparativistas do início do século XIX, é considerado o primeiro linguista a compreender que a comparação entre línguas afins poderia fundar uma ciência autônoma, cuja tarefa seria explicar uma língua por meio de 
outra - embora outros estudiosos já tivessem descoberto o parentesco entre o sânscrito e outras línguas da Europa.

\section{Os estudos histórico-comparados}

Posteriormente, os linguistas Rasmus Rask (1787-1832) e Jacob Grimm³ (17851863) incorporaram a visão histórica aos estudos comparativos, dando origem, assim, à Linguística Histórica, que, por meio do método histórico-comparativo, passou a se interessar pelas mudanças das línguas no eixo do tempo. Nesse contexto, portanto, o tema mudança linguística é o carro chefe dos estudos linguísticos, dado que a preocupação dos estudiosos era descobrir o curso histórico das formas linguísticas ou o vínculo histórico que elas mantinham entre si. Esse período histórico dedicou-se, portanto, predominantemente a estudos diacrônicos.

Essa prática foi considerada, até o final do século XIX, o único modo de se estudar cientificamente a linguagem e, por isso, pode-se dizer que as bases mais sólidas da fundação da Linguística moderna florescem num contexto de preocupações filológicas: o estudo de textos antigos, escritos, com o objetivo de se chegar a uma forma linguística original (FARACO, 2005).

O principal pressuposto teórico dessa abordagem linguística era a regularidade das mudanças, uma vez que a história de uma dada língua era reconstituída mediante mudanças registradas nas formas e nos significados dos itens linguísticos, estando, assim, comprovado o parentesco entre duas ou mais línguas quando se observava que entre elas havia palavras correlacionadas do ponto de vista semântico e/ou formal.

Além de Bopp, Rask e Grimm, outro importante representante dos estudos histórico-comparativos foi o alemão August Schleicher (1821-1868), linguista e estudioso das ciências naturais que, já no século XIX, com foco nas línguas medievais da Europa, passou a aplicar o método dessa abordagem no estudo das línguas europeias derivadas do latim, prática que ficou conhecida como Filologia ou Linguística Românica. Schleicher foi o primeiro estudioso a tentar sistematizar as ideias de Bopp (SAUSSURE, 2006), usando, para isso, diagramas em forma de árvores, que representavam as relações históricas das línguas, sem levar em conta, contudo, a variação dialetal. Essa representação ficou conhecida como modelo genealógico da linguagem.

\footnotetext{
3 Esse comparativista também é conhecido por sua produção literária em parceria com seu irmão Wilhelm Grimm (os irmãos Grimm).
} 
- Breve percurso histórico de abordagens linguísticas que antecedem e influenciam a constituição da sociolinguística variacionista

Schleicher, em consonância com as ideias de Darwin e orientando-se pelo rigor das ciências naturais - a ponto de localizar a Linguística nesse âmbito ${ }^{4}$ (CÂMARA JR., 2011, p. 64) -, concebia a língua tal como um organismo vivo, de natureza física e que independia da vontade dos falantes; por isso, trabalhava com a hipótese de que ela passaria por períodos de crescimento, maturidade e decadência. No âmbito dessas crenças, a mudança linguística foi explicada, consequentemente, em termos de degeneração, motivada por questões de ordem física, tais como, conforto anatômico ou fisiológico, ou de economia de esforço muscular (FARACO, 2005).

\section{Humboldt e Whitney}

Em contraste com as ideias naturalistas de Schleicher, dois importantes nomes do século XIX merecem destaque: o do alemão Wilhelm von Humboldt (1767-1835), na primeira metade do século, e o do norte-americano William Whitney (1827-1894), na segunda metade, sob influência do primeiro.

Humboldt é considerado um dos pensadores mais profundos do século XIX, a ponto de, na historiografia linguística, se admitir que "se a sua obra fosse melhor conhecida e mais amplamente lida, ele certamente seria colocado ao lado de Saussure como um dos fundadores do pensamento linguístico moderno" (ROBINS, 1983, p. 140).

Foi o primeiro linguista europeu a considerar a linguagem humana um sistema governado por regras ou uma capacidade viva que tem os falantes de produzir e entender enunciados, afastando, com isso, a visão de que a linguagem era simplesmente uma coleção de palavras e frases acompanhadas de significados.

A Humboldt se credita os fundamentos do estudo descritivo da linguagem (embora ele mesmo tenha feito pouca descrição), por ter apostado, num período em que o estudo histórico das línguas era predominante, na "possibilidade de se fazer uma análise de todas as línguas do mundo, a fim de serem comparadas as diferentes maneiras pelas quais a mesma noção gramatical é verdadeiramente expressa em línguas diversas" (CÂMARA JR., 2011, p. 39). Com isso, abriu caminho para os estudos tipológicos da linguagem, segundo uma orientação indutiva, embora o viés biológico tenha prevalecido nesse tipo de estudo, pelas razões que se seguem.

4 O desenvolvimento da linguagem era visto por esse alemão como o desenvolvimento de uma planta ou de um animal, tendo em vista o conceito darwinista de evolução, dominante nas ciências naturais desde esse tempo. 
Humboldt votou-se para questões de linguística geral, a fim de formular uma teoria da linguagem. Acreditando que a linguagem é uma capacidade ou uma atividade criativa incessante - energeia e não ergon $^{5}$ - da mente humana e que, por isso, não deveria ser confundida com o produto dessa capacidade, fez distinção entre língua e linguagem.

A linguagem, enquanto capacidade inata da mente humana é inseparável do pensamento, uma vez que este só ganharia forma por meio daquela. Sua organização formal seria, em consequência, de natureza dual: semântica/mental e gramatical. As consequências dessa relação entre linguagem e pensamento seria que as características de uma língua associam-se ao pensamento de seu povo: sendo herdeiro da crença de que havia línguas mais desenvolvidas do que outras - pois Humboldt acreditava que o sânscrito era a língua mais desenvolvida conhecida -, considerou que haveria tipos de pensamentos também mais desenvolvidos do que outros. Sua inovação, no entanto, consistiu em correlacionar língua, pensamento e cultura, conforme o conceito de língua que assumiu.

A língua, enquanto manifestação da capacidade da linguagem, por sua vez, se adaptaria às exigências das circunstâncias, sendo, por isso, fenômeno da história da humanidade, produto da manifestação cultural de um povo; ou seja, Humboldt acentuava tanto o aspecto universal quanto o particular da linguagem e via a diversidade estrutural das línguas como um resultado da capacidade da mente humana. Mudança linguística, consequentemente, seria um aspecto constitutivo da natureza da língua.

Sendo um produto histórico e, ao mesmo tempo, em permanente evolução, como acreditava, não haveria necessidade de se fazer distinção, nos estudos linguísticos, entre diacronia e sincronia. Tendo em vista o modo como concebeu a natureza formal da linguagem (semântico-gramatical), considerou que a distinção entre gramática e léxico era apenas pedagógica. Por fim, acreditava também que as diferentes línguas seriam o resultado das diferentes interpretações e compreensões que os falantes fazem do mundo em que vivem, ou seja, a língua moldaria a própria percepção do mundo - porque medeia mundo real e mundo mental (ROBINS, 1983). Por acreditar que a linguagem determina o pensamento, associa-se a Humboldt a noção de determinismo linguístico (LYONS, 1981).

Outro importante ponto da visão humboldtiana que marcou os estudos linguísticos respeita as observações sobre a correlação indissociável entre forma e substância. Quanto ao estudo das formas da língua, destacou duas questões que não poderiam ser desconsideradas: (i) a dificuldade na delimitação de fronteiras entre línguas; e

5 Energeia e ergon são termos gregos que significam, respectivamente, atividade e produto. 
- Breve percurso histórico de abordagens linguísticas que antecedem e influenciam a constituição da sociolinguística variacionista

(ii) o fato de que as línguas estão em constante evolução. Quanto ao estudo da substância, considerou se tratar tanto do estudo do som, quanto do espírito do homem ou o aspecto semântico-mental da linguagem (capacidade inata). Desse modo, o estudo da língua, para ser completo, deve contemplar esses dois aspectos articuladamente e chegar, assim, ao pensamento (SEVERO, 2008).

Desse modo, enquanto a diversidade de línguas, em Schleicher, era explicada pela diversidade dos órgãos fonadores humanos e, em consequência, mudança linguística era um caso de evolução natural, em Humboldt a explicação estava no espírito da língua, ou seja, na língua enquanto "canal natural pelo qual [se] chega a uma compreensão do universo que circunda o Homem" (CÂMARA JR., 2011, p. 38).

As ideias de Humboldt, porém, não tiveram grande repercussão em seu tempo, pois, a reboque da força dos estudos histórico-comparativos, prevaleceu, até a segunda metade do século XIX, a concepção evolucionista de língua, fortemente orientada pelas ideias de Schleicher.

Whitney, por sua vez, representante da segunda metade do século XIX, embora também fosse estudioso do sânscrito, por ser de formação comparativista, aluno de Bopp, foi também um profundo estudioso de Humboldt, aproximando-se, em suas concepções, muito mais deste do que da tradição em que se formou. Desse modo, dedicou-se às línguas vivas da Europa e ao desenvolvimento de leis gerais e princípios da linguagem humana. Por esse motivo fazia distinção entre filologia e linguística, creditando a essa última o papel de ciência geral da linguagem.

Também se voltou para a formulação de soluções para o aprendizado de línguas, em virtude de ter sido professor primário nos Estados Unidos num período (no final do século XIX) de grande complexidade social, proveniente da industrialização e urbanização, pelas quais passava o país, e cuja maior dificuldade era viver coletivamente (MILANI, 2007).

Nesse contexto, baseando-se em observação empírica e em necessidades práticas de seu ofício, Whitney: (i) fazia distinção entre linguagem, capacidade inata, e língua, uma instituição social concreta, como qualquer outra, tal como a religião ou as leis; (ii) com isso, considerou que a língua era transmitida de geração em geração e aprendida pela experimentação; (iii) defendeu que língua está em constante movimento, em constante formação, como resultado da atuação de duas forças: uma que atua no sentido da conservação e outra, no da transformação; (iv) desse último aspecto, reconheceu língua em dois planos complementares, passado e presente; (vi) requereu que a Linguística deveria ter um papel social, porque a língua é parte da sociedade: a função social da língua, a razão de sua existência, sua origem e diversidade (tendo em vista a relação linguagem e pensamento) deveriam ser suas preocupações. 
Quanto à mudança: (i) argumentou que não é a linguagem que muda, mas apenas a língua, enquanto materialização histórica e social daquela, levando consigo marcas do contexto em que é cunhada; (ii) defendeu que a responsabilidade pela mudança é da sociedade, e não do indivíduo (MILANI, 2007).

Conforme Koerner (2014, p. 124), são de Whitney (1867a, p. 404) as seguintes palavras:

Speech $^{6}$ não é uma possessão pessoal, mas social; ele pertence não ao indivíduo, mas ao membro da sociedade. Nenhum item existente na linguagem é o trabalho de um indivíduo; ou seja, não se pode dizer que é linguagem até que o item seja aceito e empregado por nossos semelhantes. Todo o desenvolvimento do speech, embora iniciado pelos atos de indivíduos, é operado pela comunidade.

A relevância das ideias de Whitney para os estudos linguísticos consistiu no fato de ter lançado bases para um estudo geral da linguagem ou para uma linguística geral (CÂMARA JR., 2011).

\section{Os neogramáticos}

Apesar da relevância do pensamento de Whitney, o destaque do segundo período da história moderna da Linguística foi o movimento neogramático (do qual Whitney também era representante) - a ponto de se admitir que, hodiernamente, "todos nós somos neogramáticos" (ROBINS, 1983, p. 148).

O marco desse movimento foi a publicação do primeiro número da revista "Investigação Morfológica", fundada por Hermann Osthoff e Karl Brugmann”, em 1878, a partir de quando um grupo de linguistas abandonou as idealizações românticas que conduziam os estudos para a busca da pureza de uma língua primitiva, e redirecionou os estudos para as línguas vivas contemporâneas, focalizando particularmente o plano fônico, pelas razões que se descrevem a seguir.

Os estudos histórico-comparativos, comovisto, eram conduzidos pelo pressuposto de que as mudanças linguísticas eram regulares - por isso, a história das línguas era

6 Optamos por deixar o termo speech no original por conta do problema de tradução, que ora seleciona o termo fala ora o termo discurso. Acreditamos que a referência de Whitney é ao uso, em geral, da língua.

$7 \mathrm{Na}$ verdade, o que ficou conhecido como manifesto neogramático foi o prefácio da revista, escrito por seus fundadores. 
- Breve percurso histórico de abordagens linguísticas que antecedem e influenciam a constituição da sociolinguística variacionista

reconstituída através das mudanças nas formas e nos significados das palavras; contudo, essa abordagem havia dito muito pouco sobre as exceções nessa regularidade e, caso elas não fossem explicadas, a ponto de a mudança ser vista como irregular, todos os estudos histórico-comparativos estariam comprometidos.

Dedicando-se a esta questão, os neogramáticos inauguraram o conceito de lei fonética, cujo pressuposto era o de que "são as correspondências sistemáticas existentes entre os planos fônicos das línguas que demonstram estarem elas relacionadas, e não simplesmente o fato de haver semelhanças reais entre as formas fonéticas" (ROBINS, 1983, p. 149).

Com isso, sustentaram a hipótese de que todas as mudanças fonéticas eram conduzidas pelo princípio da regularidade mecânica, descrito em termos de leis fonéticas que operam cega e necessariamente, por ser um tipo de mudança "radicalmente diferente de outros tipos de mudança" (LYONS, 1981, p. 194). Caso a lei não se aplicasse a um determinado item em processo de mudança, explicava-se o caso (a exceção) pelo conceito de analogia: quando a mente humana era capaz de interferir na mudança ao fazer associações com outras formas preexistentes.

Ou seja: em concordância com as ideias de Whitney, os neogramáticos parecem ter acionado o conceito de linguagem, enquanto capacidade imutável e inata da mente humana, para explicar fatos linguísticos "incômodos" ou que fugiam às rígidas leis teóricas postuladas. Com isso, é a partir dos neogramáticos, que tem em Hermann Paul (18461921) um de seus mais fortes representantes, que a fonética passou a ganhar destaque para o estudo histórico da linguagem, com vistas à constituição de princípios gerais que pudessem promover explicações sobre a evolução linguística de todas as línguas.

Duas concepções dos neogramáticos que se destacam são as que se seguem.

Em primeiro lugar, a de que o estudo científico da língua deve ser histórico, já que o foco de investigação estava na mudança, embora tenham abandonado a concepção especulativa dos estudos histórico-comparativos de que as línguas passavam por um processo de decadência, conforme a visão naturalista de Schleicher. Essa concepção de que o estudo da mudança só pode ser histórico decorreu do pressuposto assumido pelos neogramáticos de que ela, especialmente a mudança sonora, não pode ser observada sincronicamente. Essa hipótese nasceu dos seguintes fatos. Em 1905, o dialetólogo Louis Gauchat (1866-1942) investigou a comunidade isolada de Charmey, na Suíça, e tabulou diferenças em seis traços fonológicos na fala de três gerações (falantes com menos de 30 anos, falantes entre 30 e 60 anos e acima de 60 anos), atribuindo a essas diferenças um caso de mudança sonora - aliás, esse foi um estudo dialetológico considerado inovador 
porque correlacionou mudança linguística com faixa etária e sexo dos falantes. Paul voltou à mesma localidade, e investigou quatro dos seis traços examinados por Gauchat e, como constatou que três dos quatro traços tinham avançado na direção prevista pelo primeiro estudioso, confirmou se tratar de um caso de mudança. Com isso, Paul concluiu que a observação histórica de um traço é fundamental para uma visão precisa acerca da mudança (LABOV, 2008 [1972], p. 42).

Em segundo lugar, destaca-se a concepção de que a mudança linguística, sendo regular, segue, empiricamente, o padrão de uma curva em $S$, que pode ser assim explicado: a mudança é lenta no início, estando em uma minoria de falantes, considerados inovadores, ou mesmo em crianças; torna-se mais rápida, na medida em que passa para uma maioria de falantes, geralmente jovens; e, depois, desacelera, tendo em vista um reduzido número de falantes marginais - como idosos -, para levar adiante as formas mais antigas. A trajetória social de uma mudança, portanto, era correlacionada com a idade ou geração dos falantes (WEINREICH; LABOV; HERZOG, 2006 [1968]).

Esta explicação da mudança, fortemente descrita em termos de renovação populacional, assentava-se, em primeiro lugar, no pressuposto neogramático de que a língua não existe independentemente dos falantes que constituem uma comunidade e, em segundo, no de que a mudança decorreria de mudanças linguísticas nos indivíduos. Com foco nesse último aspecto, os neogramáticos explicaram a mudança linguística em termos de preferências psicológicas, e o idioleto era o foco, portanto, de investigação.

Mesmo assim, acreditavam também que o indivíduo não atua conscientemente sobre as leis que governam a mudança, já que a língua era produto do espírito coletivo dos grupos linguísticos (SAUSSURE, 2006). Sintetizando a questão, na explicação histórica da mudança fonética, defendiam que ela decorria de "uma ação mecânica de forças fisiológicas e psíquicas que escapam ao controle humano" (CÂMARA JR., 2011, p. 94). Disso se pode concluir que a Linguística, para os neogramáticos, só precisaria entrar em diálogo com a fisiologia e a psicologia para o estudo do que lhe era essencial: a mudança linguística (FARACO, 2005).

Os neogramáticos, assim, ao compreenderem que (i) a fonte de toda mudança linguística é o indivíduo; que (ii) a origem da mudança se dá no processo de aquisição da língua; e que (iii) as mudanças fonéticas só conhecem condicionamentos fonéticos, são automáticas, abruptas - atingindo todas as palavras ao mesmo tempo - e ocorrem sem exceção, ou seja, se aplicam a todas as palavras que satisfaçam as condições da mudança, inauguraram um psicologismo e um subjetivismo notadamente radical nos estudos linguísticos. 
- Breve percurso histórico de abordagens linguísticas que antecedem e influenciam a constituição da sociolinguística variacionista

Além do campo de estudos da fonética, o da dialetologia também influenciou fortemente os estudos neogramáticos. Acreditava-se que a investigação dos dialetos poderia fornecer evidências sobre a mudança linguística, já que eles seriam o estágio mais atual da família indo-europeia (ROBINS, 1983).

Para a análise histórica da mudança, portanto, embora considerassem dados tanto de documentos escritos quanto dados de fala, oriundos dos diferentes dialetos da época, os textos escritos foram gradualmente preteridos, pois não eram capazes de fornecer a pronúncia das línguas; o foco voltou-se, assim, para os usos orais, via dialetos.

Os neogramáticos ganharam notoriedade nos estudos linguísticos por terem desenvolvido princípios mais exatos, e introduzido rigor metodológico no estudo da mudança linguística: se Schleicher, a mais proeminente influência das abordagens anteriores, "desenvolveu seu trabalho dentro do contexto da teoria darwiniana [...] os neogramáticos quiseram fazer da linguística histórica uma ciência exata, a qual deveria adotar os mesmos métodos das ciências naturais, que alcançaram no século XIX extraordinário progresso" (ROBINS, 1983, p. 149). Ao final do século XIX, já se tratava de uma corrente dominante da Linguística. Dentre os linguistas de formação neogramática destacam-se: Meillet, Boas, Sapir e Bloomfield, tratados subsequentemente.

Para Robins (1983), o modo como os neogramáticos presumiram funcionar a lei fonética (cega e necessariamente) foi uma reificação tão indesejada quanto a afirmação mítica de Schleicher de que a língua passa por períodos de crescimento, maturidade e decadência. Justamente por isso, trata-se de um movimento que suscitou inúmeras reações, fazendo prosperar, inclusive, "um candente embate de epistemes nos últimos decênios do século XIX" (CAVALIERE, 2014, p. 614).

\section{A Geografia Linguística}

Além da escola de Karl Vossler (1872-1949), entre o final do século XIX e início do $\mathrm{XX}$, outro movimento concomitante aos estudos neogramáticos, mas que fizeram forte oposição a eles, foi a Geografia Linguística ou Dialetologia, embora o estudo dos dialetos fosse um tema caro aos neogramáticos, como já mencionado.

Nesse período, o método histórico-comparativo havia encontrado seus limites, por diversas razões. Uma delas era a impossibilidade de se aplicar a técnica de estudo do indo-europeu em línguas que não haviam desenvolvido um sistema de escrita. Para esses casos, passou-se a adotar pesquisa empírica, notadamente conduzida por antropólogos (e missionários). 
Como esses estudiosos viam a língua como qualquer outro fato antropológico, iniciou-se, mais fortemente, um movimento de dispersão da equivalência entre linguística e tradição histórico-comparativa, e o estudo das línguas vivas mundo afora entrou em vigor, fundamentado no pressuposto antropológico de íntima relação entre língua e cultura.

O objetivo dos primeiros estudos dialetológicos era produzir um retrato geográfico das diferenças linguísticas, embora os métodos utilizados não tenham sido "concebidos para examinar padrões de uso da língua [...], mas para oferecer um meio de responder perguntas sobre a história anterior da língua dentro da tradição filológica do século XIX" (MILROY; GORDON, 2003, p. 12).

Associada a esse primeiro período estava, pois, a visão romântica dos estudos anteriores, que conferiu aos pesquisadores certa nostalgia, concentrada agora na vida rural e em seus moradores, especialmente os homens mais velhos e de pouca mobilidade. O pressuposto subjacente ao interesse por esse perfil de falante era a crença de que aí estaria o dialeto mais puro ou genuíno, livre de interferências diversas. Em consequência, esse perfil de falante passou a ser visto como a fonte de dados para os estudos dialetológicos.

Ademais, os primeiros estudos tinham por objetivo confirmar a aplicabilidade do pressuposto neogramático de regularidade nas leis que regem a mudança. Em busca disso, o alemão Georg Wenker (1852-1911) foi quem primeiro incorporou à pesquisa de tradição neogramática dados empíricos que refletissem a realidade dialetológica de uma determinada localidade. Com isso, verificou que as ideias do movimento quanto à regularidade da mudança não se confirmaram, pois cada palavra parecia ter sua própria história fonética, em decorrência de influências diversas, além de analogia e empréstimos. O dialetólogo suíço Jules Gilliéron (1854-1926), posteriormente, inaugurou a prática de se investigar vocábulos específicos, único dado linguístico completo, para ele (CÂMARA JR., 2011).

Por isso, nos primeiros estudos dialetológicos, compreendia-se que palavras específicas, como um tipo de ser vivo, entravam em competição com outras palavras. Empréstimos linguísticos e formas do intercâmbio oral - em contraste com os estudos comparativos que focalizavam dados escritos - passaram a ser centrais para a explicação da mudança linguística, e a metodologia de obtenção desses dados era explicitamente metalinguística, pois levava o falante nativo a refletir sobre as formas da língua que empregava. Tratou-se, assim, de uma nova abordagem para o estudo histórico-comparativo da linguagem sob o título de reconstrução interna (CÂMARA JR., 2011).

O objetivo dos pesquisadores dessa vertente era, então, traçar cartas geográficas, por meio de "linha isoglóssica, isto é, os traços linguísticos, isolados, como ponto de 
- Breve percurso histórico de abordagens linguísticas que antecedem e influenciam a constituição da sociolinguística variacionista

partida para a constituição" (CÂMARA JR., 2011, p. 121) de mapas linguísticos, tendo como central o conceito de dialeto enquanto uma abstração distintiva, constituída por meio de um conjunto de traços linguísticos específicos; desse modo, traços linguísticos, considerados mudanças linguísticas particulares, delimitavam as linhas isoglóssicas.

No entanto, os estudos dialetológicos, quanto mais de perto examinavam um dialeto, mais fizeram ver que: (i) o número de isoglossas necessárias para a delimitação de um dialeto era arbitrário, pois havia grande flutuação entre fronteiras dialetais; (ii) uma mesma mudança fônica poderia chegar mais cedo para uma palavra do que para outra; (iii) a estratificação social poderia promover variação social e individual, em virtude do próprio julgamento que os falantes tendem a ter em relação à "fala correta". E todos esses aspectos contrastavam com as ideias neogramáticas. Com isso: os primeiros estudos dialetológicos, que tinham por objetivo confirmar a hipótese neogramática, acabaram por refutá-la, pois a mudança linguística se mostrava muito mais complexa.

Com tudo isso, embora a distribuição de variantes específicas, no espaço, lançasse luz sobre a mudança no tempo, era preciso admitir que limites temporais eram tão imprecisos quanto os limites geográficos. Por isso, se os primeiros estudos dessa abordagem, no final do século XIX, dedicaram-se a estudos históricos, os do início do século XX passaram a se dedicar à descrição das línguas contemporâneas.

Da Europa, em 1931, dialetólogos suíços foram aos Estados Unidos orientar um grupo de linguistas quanto ao trabalho de campo. Como resultado, em 1946, por exemplo, um dos linguistas orientados, Raven McDavid (1911-1984), publicou um artigo intitulado "Dialect Geography and Social Science Problems" e, em 1948, fez uma análise social da variação no segmento fonológico "PostVocalic /r/ in South Carolina" (KOERNER, 2014, p. 125).

Soma-se a isso o fato de o dialetólogo empirista Ferdinand Wrede (18631934), discípulo de Wenker e quem muito cedo traçou "paralelos entre a etnografia e a dialetologia, distinguindo as vertentes individual-linguística [...] e social-linguística" (KOERNER, 2014, p. 125), ter sido orientador de doutorado de Max Weinreich (1894-1969), pai de Uriel Weinreich (1926-1967). Este último, importante nome na linguística norteamericana, dedicou-se ao estudo do bilinguismo, sob a perspectiva sociográfica, tema caro ao contexto de seu país.

Na década de 1950, consolidou-se o movimento de dialetologia urbana, em decorrência de preocupações com os problemas educacionais enfrentados por crianças de classe trabalhadora. Enquanto os estudos dialetológicos rurais pressupunham uma estrutura social estática, os estudos dialetológicos urbanos (como o de Bernstein, 1958) 
passaram a destacar a dinâmica social, especialmente em termos de classes (LE PAGE, 1998).

Em síntese, tudo isso significou, para os estudos dialetológicos de contexto norteamericano, "um tipo particular de aproximação à língua em geral e a questões de mudança linguística, cuja orientação é sociológica" (KOERNER, 2014, p. 124). Até a década de 1960, principalmente em contexto norte-americano, foi por meio do modelo da dialetologia que a variação linguística foi estudada.

\section{Fechando a seção}

Entre o final do século XVIII e início do XX, vê-se na história dos estudos linguísticos uma crescente pluralidade de meios de se estudar a linguagem humana, em decorrência de distintas questões de pesquisa. Diante desse cenário,

[...] as realizações mais significativas da ciência linguística do século XIX podem resumir-se nestes dois aspectos: o estabelecimento dos princípios e dos métodos para a classificação [das famílias linguísticas] e, o que é mais importante, o desenvolvimento de uma teoria geral das transformações linguísticas e das relações entre as línguas. (LYONS, 1979, p. 22).

Orientando esses dois aspectos marcantes na linguística do final do século XVIII e todo século XIX, pode-se dizer que predominou o ponto de vista de que as línguas eram regidas por leis naturais, de sorte que "a uniformidade da natureza transformou-se em dogma generalizado" (ROBINS, 1983, p. 149), embora embriões de uma mudança na perspectiva filosófica dos estudiosos sobre o lugar a partir do qual a Linguística deveria ser pensada - de enquadrada entre as ciências naturais para enquadrada entre as ciências sociais - tenham florescido já no final do século XIX.

\section{A linguística no século XX}

Nesta seção retomam-se, brevemente, dois importantes movimentos que marcaram os estudos linguísticos do século XX: (i) o estruturalismo e (ii) o gerativismo.

\section{O estruturalismo}

Como representante mais significativo do primeiro movimento, o linguista suíço Ferdinand de Saussure (1857-1913), também de formação neogramática, foi tão importante 
- Breve percurso histórico de abordagens linguísticas que antecedem e influenciam a constituição da sociolinguística variacionista

para a história da Linguística que, a partir dos primeiros anos do século XX, passou a ser considerado o "pai"8 da Linguística moderna. Sua notoriedade, porém, já se consolidara desde o século XIX, com a publicação, em 1878, de Mémoire sur le système des voyelles dans les langues indo-européennes ${ }^{9}$ : um texto de trezentas páginas sobre o sistema vocálico original das línguas indo-europeias (COSTA, 2015).

Nesse texto, Saussure, sob influência das ideias de Humboldt e de Whitney, promoveu uma reorientação conceitual nos estudos linguísticos, na medida em que afastou da explicação linguística o conceito de som ou o detalhamento fonético, bem como noções fisiológicas (movimentos musculares) e acústicas, conforme tradição que Ihe precedeu, e orientou-se para as unidades que comporiam os sons, entendendo-as como padrões mentais socialmente compartilhados (COSTA, 2015).

Tratou-se, assim, não de uma inovação teórica, mas de um trabalho que congregou tendências dos estudos linguísticos já existentes, reconhecendo o grande serviço prestado por elas (SAUSSURE, 2006), e as levou a um passo adiante, divergindo, inclusive, de certos aspectos das ideias daqueles que lhe inspiraram, como Whitney ${ }^{10}$. Esse foi o redirecionamento que constituiu a base da Linguística do século XX (COSTA, 2015).

Considerando que o foco dos linguistas de seu tempo estava errado, dado que as tecnicidades fonéticas não interessavam a uma teoria sobre a linguagem, Saussure se empenhou em delimitar o que seria, então, o objeto da Linguística e do linguista. Nessa empreitada, reconheceu que os limites entre a Linguística e muitas outras ciências (Sociologia, Psicologia Social etc.) nem sempre eram nítidos - embora já tivesse concebido a nítida distinção entre ela e a Filologia (SAUSSURE, 2006), conforme Whitney advertira, e reconhecido também que "as questões linguísticas interessavam a todos [...] que tenham que manejar texto" (SAUSSURE, 2006, p. 14).

A despeito da interseção que mantinha com outras ciências, bem como dos muitos objetos a que poderia se dedicar, uma Linguística muito bem delimitada, longe de qualquer aglomerado confuso de coisas heteróclitas, nasceu, em primeiro lugar, da divisão entre linguagem e língua, assim definidas por Saussure: (i) a linguagem é uma

8 A versão (canônica) de que Saussure é o "pai" da linguística moderna deve ser relativizada, uma vez que vem sendo contestada desde a década de 1970. Koerner, em sua tese de doutorado de 1971, por exemplo, mostra como ideias e conceitos saussurianos provêm de autores como Whitney e Paul. Esse, contudo, não é nosso foco de discussão, neste texto.

9 Mémoire sobre o Sistema Primitivo de Vogais nas Línguas Indo-europeias.

10 Saussure discorda, por exemplo, da ideia de Whitney de que a língua é uma instituição social de mesma natureza que as demais. 
faculdade multiforme e heteróclita, porque se assenta sob diferentes domínios, ao mesmo tempo físico, fisiológico e psíquico; pertence ao domínio individual e ao domínio social, concomitantemente, e não se deixa classificar em nenhuma categoria dos fatos humanos, do que decorre a impossibilidade de se determinar sua unidade; (ii) a língua é apenas uma parte (essencial) da linguagem; é um produto social da faculdade da linguagem; um conjunto de convenções necessárias adotadas pelo corpo social para possibilitar o exercício de tal faculdade pelos indivíduos.

Dada a impossibilidade de se determinar a unidade da linguagem que pudesse ser estudada, Saussure elegeu como objeto de estudo da Linguística a língua (SAUSSURE, 2006), o sistema linguístico, enquanto conjunto de formas fonéticas, gramaticais e lexicais, um sistema de formas idênticas a si mesmas e imutáveis -, tendo em vista sua lógica interna específica (BAKHTIN [VOLOCHÍNOV], 2014 [1929]). Concebeu, portanto, a língua como uma estrutura abstrata, constituída por um sistema de relações recíprocas em que uma forma linguística devia sua existência "ao fato de ser algo mais que todas as outras formas linguísticas" (CÂMARA JR., 2011, p. 130).

Ademais, Saussure advogava que a língua é de natureza sígnica e, portanto, a Linguística deveria ser a ciência dos signos. Contudo, como (i) se voltou para as relações entre os signos - mais do que para o signo em si -, aproximou-se da matemática quanto ao culto à forma fixa, racional e imutável; e (ii) considerou que o signo linguístico era uma entidade psíquica de duas faces (o significado e o significante), cuja relação é arbitrária, e todos os princípios que lhe são estruturantes foram considerados exclusivamente internos, imanentes, independentes de qualquer ato de criação individual ou de qualquer menção aos significados ideológicos ou históricos que o sistema pudesse ter para os falantes. Assim nasceu a Linguística enquanto disciplina: autônoma, em relação às outras ciências, e dedicada exclusivamente às relações internas das línguas.

Por outro lado, Saussure argumentou que os sistemas linguísticos são um fato social de natureza imperativa e geral (SAUSSURE, 2006). Com isso, "Saussure estava dizendo várias coisas: que eles são diferentes dos objetos naturais, embora não menos reais que esses; que são externos aos indivíduos e sujeitam-nos à sua força restritiva; que são sistemas de valores mantidos por convenção social" (LYONS, 1981, p. 205).

Esses foram os princípios que forneceram consistência formal à intuição de que as línguas são organizadas estruturalmente; por isso, Saussure é considerado o precursor do pensamento estruturalista, uma das correntes da linguística formal. 
- Breve percurso histórico de abordagens linguísticas que antecedem e influenciam a constituição da sociolinguística variacionista

A defesa de que "a linguística é o estudo do padrão linguístico que se encontra subjacente em todo ato de discurso"11 (CÂMARA JR., p. 131-132; grifos nossos), no entanto, contrastava com a realidade da língua em uso, repleta de variações entre os falantes e num mesmo falante. Por isso, com o objetivo de descrever um sistema perfeitamente ordenado, Saussure fez distinção entre fala (parole), o lugar das variações individuais, e língua (langue), sistema abstrato coletivo, subjacente à fala de um dado momento histórico e independente das mudanças no curso do tempo, o que tinha como pressuposto a compreensão de que a língua é um sistema invariável.

Desse modo, a fala seria o lugar de expressão do pensamento individual - por isso, o lugar da variação -, e a língua, o sistema abstrato comum a toda comunidade, invariável e instituído socialmente: a dicotomia langue-parole também fez nascer as dicotomias social-individual (BAKHTIN [VOLOCHÍNOV], 2014 [1929]), invariância-variância.

A mudança linguística, tema caro aos estudos dos dois séculos anteriores, perde lugar, nessa corrente, para o estudo descritivo das relações internas entre os elementos de um sistema linguístico; e, com isso, afasta-se também a visão de mudança enquanto degeneração do sistema, tese da tendência evolucionista que havia predominado até a segunda metade do século XIX.

Ao admitir o valor positivo da diversidade linguística, o estruturalismo saussuriano admite também a singularidade dos sistemas linguísticos, ou seja, que as relações de um sistema não são universais. Em resultado, pode-se dizer que o estruturalismo assumiu uma visão relativista, em oposição à universalista, da linguagem.

A descrição dos princípios regentes de um sistema, num espaço de tempo aparentemente fixo, constitui o que Saussure considerou a dimensão sincrônica dos estudos linguísticos, contrapondo-se, assim, à tradição diacrônica anterior ${ }^{12}$.

Mesmo reconhecendo a dimensão histórica ou diacrônica da língua, para Saussure (2006), diacronia e sincronia não tinham a mesma importância: a dimensão sincrônica deveria prevalecer, além de ser anterior ao estudo diacrônico, pois, para estudar mudanças linguísticas, primeiro se estuda diferentes estados de língua e depois eles são comparados,

11 Câmara Jr. (2011) usa o termo discurso, ao se referir ao trabalho de Saussure, como alternativo à fala.

12 Retome-se os neogramáticos, que (i) negavam a descrição linguística como um método científico válido e, por isso, (ii) reforçavam a tradição de se considerar apenas a dimensão diacrônica ou histórica nos estudos linguísticos. O fato de Saussure ter se oposto a esses pontos não significa que tenha negado a dimensão diacrônica da língua; antes reconheceu a interdependência de dois princípios linguísticos: o de mutabilidade linguística ao longo do tempo, orientando os estudos diacrônicos da Linguística Histórica, e o de relativa imutabilidade das línguas, orientando a perspectiva sincrônica saussuriana (FARACO, 2005). 
mesmo sabendo que os limites de um estado são indeterminados - "[...] pode ser de 10 anos, uma geração, um século e até mais" (SAUSSURE, 2006, p. 118).

Tratou-se, portanto, da sistematização de uma visão que simplificava o constante movimento das línguas para garantir a estabilidade do objeto de estudo delineado idealizado - por Saussure (FARACO, 2005, p. 96), o que mudou os rumos da Linguística: de predominantemente histórica, no século XIX, passou a ser predominantemente descritiva, no século XX. Isso significou a escalada de uma visão atomista da mudança linguística, segundo a qual as mudanças não ocorriam num complexo sistema de interrelações, mas em elementos isolados do sistema, dado que o estudo diacrônico, para Saussure, excluía a noção de sistema.

Neste ponto, cabe destacar que a abordagem dialetológica, proeminente nesse início de século, apesar de relativamente independente da Linguística, também foi influenciada pelos estudos estruturalistas, a ponto de se consolidar uma dialetologia estrutural, especialmente nos Estados Unidos.

Essa vertente dos estudos dialetológicos consistia em uma "tendência de tratar elementos linguísticos (particularmente sons) isoladamente, e não como partes de um sistema" (MILROY; GORDON, 2003, p. 16). Um dos representantes desse tipo de estudo foi o linguista Uriel Weinreich (1926-1967), interessado em anular as diferenças entre a dialetologia e a análise linguística estrutural.

\section{Meillet e Martinet}

Apesar de Saussure tratar a língua como fato social, foi apenas por meio de um de seus discípulos, o francês Antoine Meillet (1866-1936), que as condições sociais passaram a ser vistas como relevantes para a explicação da língua e, consequentemente, para a explicação do que era foco desse linguista: as causas da mudança linguística (KOERNER, 2014).

São de Meillet (1921, p. 16-17 apud LABOV, 2010, p. 185), por exemplo, as seguintes palavras:

A única variável a que podemos recorrer para explicar a mudança linguística é a mudança social, da qual variações linguísticas são apenas consequências [...]. Devemos determinar qual estrutura social corresponde a uma dada estrutura linguística, e como, de um modo geral, as alterações na estrutura social se traduzem em mudanças na estrutura linguística. 
- Breve percurso histórico de abordagens linguísticas que antecedem e influenciam a constituição da sociolinguística variacionista

Sob a influência de um contexto em que a sociologia também se consolidava, no final do século XIX, para Meillet, entre outros aspectos: (i) a língua, diferentemente do que acreditava Saussure, não era um sistema autônomo de relações, pois os fatos sociais poderiam nela interferir; (ii) a Linguística deveria estar entre as ciências sociais, integrando a antropologia; (iii) um dos trabalhos da Linguística seria buscar correlações entre mudança linguística e outros fatos sociais; (iv) a principal condição da mudança linguística é a condição heterogênea da língua, resultante da heterogeneidade da sociedade (FARACO, 2005).

Os estudos de Meillet, para a comprovação de tais suposições, foram baseados em dados empíricos e evidenciaram que diferenças sociais resultavam em diferenças linguísticas. Por isso Meillet pode ser considerado uns dos primeiros linguistas "a tentar formular uma orientação teórica para o estudo da história linguística que incorporasse a sempre heterogênea realidade sociocultural das línguas" (FARACO, 2005, p. 155). Ficou, contudo, na primeira metade do século XX, à margem da perspectiva hegemônica na época, o estruturalismo saussuriano.

Um dos alunos de Meillet que também merece destaque é o francês André Martinet (1908-1999), que se dedicou aos estudos dialetais, fazendo descrição de seu próprio dialeto (KOERNER, 2014), e também ao tema da mudança linguística. Quanto a esse último tópico, assumiu uma perspectiva sistêmica, diferentemente de Saussure, embora considerando um constante desequilíbrio nos sistemas, tendo em vista a atuação de duas forças contraditórias: (i) a necessidade comunicativa humana, que exige oposições distintivas na língua, evitando, assim, homonímias; e (ii) a tendência humana de reduzir o esforço nas atividades física e mental, conduzindo à eliminação de diferenças linguísticas (FARACO, 2005). Mudança, portanto, para esse linguista, seria consequência dessas duas constantes pressões que atuam sobre os sistemas.

A despeito da contribuição metodológica de sua visão estruturalista para a Linguística Histórica, ao admitir que a mudança pode ser analisada sistematicamente, ou seja, em relação a outros elementos da língua, a visão de Martinet ainda se assenta na concepção de que a explicação da mudança está em fatores eminentemente internos, imanentes. Talvez isso se explique pelo fato de o autor ter sido um representante do pensamento da escola do Círculo Linguístico de Praga, um movimento estruturalista constituído por um grupo de críticos literários e linguistas estabelecidos na cidade de 
Praga, nas décadas de 1920 e 1930, que desenvolveu significativamente o campo da fonologia ${ }^{13}$.

Esta escola, conduzida especialmente pelo linguista russo Nikolai Trubetzkoy(18901938), consolidou uma teoria fonológica, segundo a qual os sons da fala pertenceriam à parole, e o fonema, ao sistema da langue, como se pode ler no excerto a seguir: '[...] ao estudarem as línguas como sistemas de elementos internamente relacionados, os linguistas de Praga não trataram o fonema como classe de sons ou recurso descritivo, e sim como unidade fonológica complexa que se realiza através dos sons da fala" (ROBINS, 1983, p. 166).

Adverte-se, porém, que, mesmo sendo de orientação estruturalista, os estudos da escola de Praga afastaram-se de Saussure nos seguintes aspectos: (i) acreditavam que o estudo diacrônico não excluía a noção de sistema, assim como a descrição sincrônica também não excluía a noção de evolução; e, em consequência, (ii) afirmavam que a mudança é sistêmica (FARACO, 2005). Com isso, pode-se concluir que foi no campo da fonologia, por meio dos estudos da escola de Praga, que o estruturalismo se tornou mais formal e se consolidou na Europa, incluindo aí a Rússia, no início do século XX.

\section{O formalismo norte-americano}

No contexto dos estudos estruturalistas, a linguística praticada nos Estados Unidos nas primeiras décadas do século XX, além da dialetologia estrutural, também merece destaque, já que desenvolveu um tipo específico de estruturalismo: enquanto o estruturalismo europeu construiu um aparato teórico para explicar a linguagem, o norte-americano se dedicou a descrever, o mais rápida e eficientemente possível, línguas indígenas e, por esse motivo, ficou conhecido como descritivismo.

Os linguistas norte-americanos desenvolveram métodos rigorosos de descrição linguística, com a prática de permutação entre segmentos de um nível, a partir dos quais poderiam derivar generalizações. Tinham como princípio metodológico que as generalizações do campo da fonologia, da morfologia, da sintaxe e da semântica deveriam ser feitas separadamente e nesta ordem (MILROY; GORDON, 2003).

\footnotetext{
13 Como visto, até o século XIX o foco esteve na fonética, localizada no campo da fisiologia e da acústica, com base na visão naturalista predominante na época. Mesmo assim, ao final do século, a distinção conceitual entre "sons cujas diferenças dependem do contexto fonético [...] e sons que servem para estabelecer oposições significativas" (ROBINS, 1983, p. 165) já estava feita, embora a distinção terminológica entre som da fala (ou fone) e fonema tenha sido formalizada posteriormente, pelo linguista polonês Baudouin de Courtenay, em 1983.
} 
- Breve percurso histórico de abordagens linguísticas que antecedem e influenciam a constituição da sociolinguística variacionista

Os descritivistas norte-americanos reforçaram o princípio formal de que cada língua tem sua própria organização e que, portanto, não deveriam ser comparadas ou submetidas a apreciações avaliativas em relação a outros sistemas linguísticos (CAMACHO, 2013).

A orientação desse pensamento advinha da posição relativista da antropologia, dado que os pesquisadores desse campo é que se destacaram na prática de descrever línguas vivas, conforme mencionado anteriormente. Um dos nomes mais relevantes, nos Estados Unidos, nesse período foi o do antropólogo alemão Franz Boas (1858-1942), com o trabalho de descrever e classificar as línguas indígenas americanas. Seu trabalho destacou (i) o aspecto regular das línguas (padronização), (ii) a inconsciência desse padrão por parte dos falantes e (iii) o papel preponderante dos empréstimos linguístico na difusão de traços.

O trabalho de Boas influenciou fortemente o linguista e também antropólogo Edward Sapir (1884 -1939), formalista que se aproximava da concepção saussuriana de que a linguagem é autônoma em relação à cultura e ao pensamento - pois é molde que serve a todo tipo de cultura e a todo tipo de pensamento -, e de que o trabalho do linguista é descobrir padrões intrínsecos às formas linguísticas; seu foco também esteve na dimensão sincrônica da língua.

O trabalho de Sapir foi notadamente em torno da descoberta de padrões fonológicos formais, embora também fosse conhecedor do problema histórico da linguagem. Assim, destacou-se por: (i) fornecer uma doutrina mais coerente e homogênea que a de Saussure sobre a dimensão diacrônica da linguagem; (ii) rejeitar a separação entre mudança fonética e mudança morfológica feita pelos neogramáticos; (iii) conceber rumos claros quanto à direção das mudanças linguísticas, embora completamente distante da visão naturalista de Schleicher; (iv) propor uma classificação tipológica das línguas (MATTOSO CAMARA, 2011).

Com os trabalhos de Sapir, a linguística norte-americana se tornou mais descritiva e formalista; e, apenas em 1957, um de seus assistentes, Benjamin Lee Whorf, promoveu um estudo empírico para verificar suas ideias. Boas, Sapir e Whorf têm em comum o fato de serem herdeiros de Humboldt quanto à compreensão relativista de que cada língua tem sua própria organização gramatical e que disso resulta diferentes possibilidades, para seus falantes, quanto à interpretação e compreensão do mundo.

A hipótese de que a língua organiza a experiência, moldando o mundo e a realidade dos falantes, ou seja, de que a língua socialmente constituída "influencia o modo como a sociedade concebe a realidade e, ao mesmo tempo, exerce uma função heurística na 
percepção da realidade" (CAMACHO, 2013, p. 27) é referida na literatura como hipótese Sapir-Whorf ${ }^{14}$.

Foi com base nessa hipótese que a Linguística estruturalista norte-americana acreditou que cada sistema linguístico deveria ser descrito e analisado particularmente por meio de suas diferentes manifestações, ou seja, considerando tanto os registros falados mais informais quanto os escritos mais formais, passando pelos registros literários, sem qualquer tipo de seleção dos dados.

Esse tipo de estruturalismo se consolidou com os trabalhos de Leonard Bloomfield (1887-1949), "linguista norte-americano dos mais importantes do século XX" (FARACO, 2005, p. 148) que, influenciado pelo behaviorismo - abordagem psicológica baseada no comportamento - colocou as formas linguísticas, principalmente considerando o campo da fonologia, num nível de observação mecânico, pois puramente objetivo ${ }^{15}$, na esteira da escola de Praga.

Bloomfield, com foco na diversidade estrutural das línguas, considerou que o conceito neogramático de que as leis fonéticas não admitiriam exceções era apenas um modo de dizer que fatores não fonéticos, como frequência de uso ou significado das palavras, não podiam interferir na mudança sonora. O ponto central da herança neogramática, portanto, segundo Bloomfield, era discernir a extensão da regularidade fonética e o significado das irregularidades (FARACO, 2005).

Seguindo essa tendência neogramática, Bloomfield abandonou a semântica e se dedicou essencialmente ao método e à análise formal no trabalho de descrição linguística, reposicionando o estudo da linguagem para o campo das ciências naturais. Isso significou que Bloomfield não se dedicou ao tema mudança linguística, porque assumiu o pressuposto de que ela não pode ser observada diretamente, principalmente no que concerne à mudança sonora ${ }^{16}$.

14 Justamente por ter sido desenvolvida por esses dois linguistas: o primeiro formulou os pressupostos conceituais, e o segundo encontrou evidências empíricas para os pressupostos de Sapir, ao analisar a categoria de tempo na língua hopi, uma língua indígena dos EUA.

15 Sua prática consistia em fazer comparações dialetais, dentro de uma mesma língua, de sistema de fonemas, a fim de reconstruir, através do tempo, diferentes estados linguísticos, método claramente influenciado pela Geografia Linguística. Considerou que a semântica não era cientificamente manipulável, pretendendo deixá-la de lado, mesmo tendo usado critérios semânticos para opor formas mínimas, pois dois segmentos fonêmicos poderiam ser apenas variantes de uma mesma forma linguística e, ao mesmo tempo, um mesmo segmento fonêmico poderia representar mais de uma forma.

16 Cf. explicação sobre essa posição de Bloomfield em Labov (2008 [1972]). 
- Breve percurso histórico de abordagens linguísticas que antecedem e influenciam a constituição da sociolinguística variacionista

Passou então a focalizar a sintaxe, ao descrever a estrutura da frase em termos de constituintes imediatos, ou seja, componentes cada vez mais simples e menos extensos, consolidando o método da distribuição, que focalizava a possibilidade de relacionamento dos fonemas e dos morfemas no eixo sintagmático.

Entre a década de 1930 e final de 1950, período em que a linguística enquanto abordagem autônoma se estabelecia mais fortemente nas universidades dos Estados Unidos, a influência formalista de Bloomfield foi tão notável que ficou conhecido como "era bloomfieldiana".

\section{O gerativismo}

Rompendo com essa era, de orientação descritiva e comprometida com uma concepção empirista e indutiva de se fazer ciência, a partir da década de 1950 ocorreu a mais radical e importante mudança nos rumos dos estudos linguísticos, com a publicação, em 1957, de Estrutura sintática (Syntactic structures) (1957), do norte-americano Noam Chomsky (1927-), que retomava uma concepção racionalista de ciência, baseada na construção de modelos teórico-indutivos.

O principal pressuposto desta abordagem nasce do fato de as línguas poderem apresentar usos infinitos, a partir de recursos muito limitados. Diante disso, admite-se que as línguas humanas têm a propriedade da recursividade. Além disso, acredita-se também, na abordagem, que o fato de os usos da língua serem, de certa forma, imprevisíveis, evidencia uma qualidade peculiar da mente humana, que é a criatividade. Contudo, como os usos linguísticos são estruturados, compreensíveis, a criatividade da mente humana para o uso da língua deve ser regida por regras. Com esse raciocínio, admite-se que "as regras que determinam a produtividade das línguas humanas têm as propriedades formais que têm em virtude da estrutura da mente humana" (LYONS, 1981, p. 213):

E é aqui que entra a gramática gerativa propriamente. Os enunciados que produzimos têm uma certa estrutura gramatical: eles estão em conformidade com regras de boa formação identificáveis. À medida que conseguimos especificar essas regras de boa formação, ou gramaticalidade, teremos fornecido um relato cientificamente satisfatório daquela propriedade da linguagem - [sua recursividade].

Chomsky, com esses pressupostos, inaugurou a abordagem gerativotransformacional da Linguística que, mais ambiciosa do que qualquer outra que lhe 
antecedeu, objetiva descrever a competência linguística ${ }^{17}$ do falante nativo, por meio de símbolos matemáticos e lógicos, chegando-se, assim, a uma teoria de linguagem, cuja orientação é fortemente inatista. Em outros termos, acredita-se, nessa abordagem, que a linguagem é uma propriedade da mente humana; e a função da Linguística é desenvolver um modelo do mecanismo mental - por isso é uma abordagem mentalista - que orienta a produtividade das línguas. Esse modelo é chamado tecnicamente de gramática universal (ROBINS, 1983; FARACO, 2005).

Como o objetivo da abordagem é descrever o aspecto gerativo da língua enquanto faculdade humana inata e, como todos os humanos, em condições de normalidade, são dotados dessa capacidade, o foco da investigação está no falante enquanto exemplar da espécie e exemplar de uma comunidade homogênea, no que respeita à sua intuição sobre a língua. Trata-se, assim, de uma abordagem baseada na psicologia individual, segundo a qual investiga-se a intuição do falante, que é exemplar da intuição de todos os indivíduos e meio para se obter a realidade da faculdade da linguagem.

Weinrench, Labov e Herzogis (2006), ao revisarem a prática dos gramáticos gerativistas, relembram que Chomsky considerou a diversidade real do comportamento linguístico irrelevante para sua teoria, e justificou tal posicionamento com o argumento de que esta também tinha sido a posição dos fundadores da linguística geral moderna, em referência a Saussure.

Desse modo, propõe-se a descrição de uma gramática universal, independente do que ocorre em situações reais do uso da língua - dado que o foco da abordagem é aquilo que as línguas têm em comum - por isso, os dados que se vinculam à análise dos gerativistas são deduzidos da teoria, ou seja, são construídos intuitivamente pelo pesquisador.

Em busca de generalizações para uma teoria sobre a capacidade para a linguagem, acreditam que nenhum corpus pode servir de base para as generalizações de que precisam, já que todos eles tendem a ser uma coleção parcial das possibilidades de uso. Para Lyons (1981), em diversos aspectos, o gerativismo continua a tradição estruturalista, tais como: (i) na continuidade da tradição, da era blomfieldiana, de se estudar a sintaxe e de vê-

17 O termo competência linguística se opõe ao termo desempenho linguístico, na abordagem: o primeiro, objeto de interesse dos gerativistas, é compreendido como a capacidade inata para produzir e interpretar frases bem formadas (gramaticais), distinguindo-as das malformadas (agramaticais); o segundo refere-se à manifestação da competência nos usos reais da língua. A partir da década de 1980, esses conceitos foram revistos na teoria, optando-se por fazer distinção entre língua interna e língua externa, embora a mudança terminológica não tenha promovido alterações conceituais significativas (MILROY; GORDON, 2003).

18 Doravante WLH. 
- Breve percurso histórico de abordagens linguísticas que antecedem e influenciam a constituição da sociolinguística variacionista

la como independente da semântica; (ii) na distinção que faz entre sistema linguístico e uso desse sistema (à semelhança da distinção langue-parole); (iii) e na distinção entre competência e desempenho (também à semelhança da distinção langue-parole $)^{19}$. Com essa proposta, fortaleceu-se o formalismo linguístico em território estadunidense.

Nesse contexto, a mudança linguística é vista de duas diferentes maneiras, ao longo da história da própria abordagem: (i) até a década de 1970, considerando gramática como um sistema de regras específicas, a mudança é vista como um processo que altera as regras da gramática - eliminando algumas regras, inaugurando outras ou mesmo reordenando sua aplicação -; (ii) a partir de 1970, com a noção de que a gramática universal é conduzida por princípios gerais e se constitui por um conjunto de parâmetros variáveis, que restringem as gramáticas, mas admitem caminhos alternativos, a mudança passou a ser vista não mais em termos de alterações de regras, mas alterações na fixação de parâmetros.

Como um parâmetro é visto como um conjunto de fenômenos inter-relacionados, a mudança de um único parâmetro pode explicar uma série de mudanças linguísticas aparentemente não correlacionadas, continuando, assim, na explicação da mudança, a perspectiva estruturalista e sistemática (FARACO, 2005).

Essas duas diferentes formas de explicar a mudança linguística parecem ser indícios da crescente abstração da abordagem: de conveniência metodológica para descrição das regras linguísticas da teoria gerativa, passou a ser a especificação de princípios e parâmetros que limitam a forma de gramáticas universais gerais (MILROY; GORDON, 2003).

\section{Fechando a seção}

Com essas duas últimas correntes, o estruturalismo e o gerativismo, a linguística se tornou marcadamente formal, excluindo de seu escopo qualquer explicação social ou histórica, embora por diferentes razões: no estruturalismo, porque o que importa é a descrição do sistema linguístico enquanto realidade abstrata, cujas leis são pressupostas como imanentes e irredutíveis a qualquer tipo de lei que lhe seja exterior (sociológica, artística, psicológica etc.); no gerativismo, porque, assumindo-se o pressuposto de que a língua é uma capacidade da espécie humana, o trabalho do linguista passou a ser a descrição dessa capacidade, ou seja, a construção de uma teoria sobre como ela se constitui.

19 Veja por que Faraco (2005) considera o Gerativismo um "estruturalismo com roupa nova". 
Além disso, excluíram também a variação, ambos em busca de um sistema abstrato e subjacente ao uso, de natureza invariável.

\section{Balanço e perspectivas}

A breve (e incompleta ${ }^{20}$ ) revisão histórica do pensamento filosófico-linguístico entre o final do século XVIII e meados do XX indica como as distintas abordagens linguísticas se ocuparam de variadas questões e, com isso, foram constituindo seus objetos em torno de diferentes concepções de língua - sistema natural, para os estudos históricocomparativos; sistema psicológico, para os neogramáticos; sistema abstrato de relações sígnicas, para o estruturalismo; sistema abstrato de regras que formam sentenças, para o gerativismo. A despeito das diferenças, todas elas têm em comum, contudo, o fato de terem estabelecido objetos homogêneos, dissociados das condições históricas, sociais e culturais das sociedades que usam a língua.

Concomitante a essas abordagens, o período também foi marcado pelas ideias de alguns pesquisadores, tais como, Humboldt, Whitney, Meillet e Martinet que, diferentemente do pensamento filosófico-linguístico predominante de suas épocas, vindicaram o aspecto social da língua, destacando a necessidade de se compreender a sociedade, para se compreender os fatos linguísticos. Mas, como visto, não foi esse tipo de pensamento que predominou até meados do século XX nas abordagens linguísticas mais praticadas do ocidente.

É, pois, "motivado por uma reação contra o formalismo linguístico" (FIGUEROA, 1994 , p. 1) que nasce o campo sociolinguístico, na década de 1960, em contexto estadunidense. Recobrindo diferentes práticas de pesquisa ${ }^{21}$, a SV, uma delas, nasce com o compromisso de ser o "estudo da estrutura e da evolução da língua, dentro do contexto social da comunidade" (LABOV, 2008 [1972], p. 216), com o compromisso, portanto, de correlacionar o mundo linguístico com o mundo social.

\footnotetext{
20 Na historiografia da linguística, outros autores ainda são mencionados como precursores da sociolinguística. O alemão Hugo Schuchardt (1842-1927) e o italiano Graziadio Isaia Ascoli (1929-1907), por exemplo, são autores que merecem atenção especial, pois se opuseram radicalmente aos neogramáticos, sendo considerados, respectivamente, o pai da crioulística e o pioneiro nos estudos dos "dialetos" italianos. Neste texto, contudo, por questões de espaço, nosso objetivo é resgatar apenas uma parte da história dos estudos linguísticos que antecedem e influenciam a constituição da sociolinguística, ficando o alerta de que muitas outras leituras devem ser feitas sobre a temática, a fim de se ter um panorama mais amplo do que o aqui recuperado.

21 O campo Sociolinguístico se estabelece a partir de um conjunto de eventos acadêmicos, na década de 1960, que reuniu pesquisadores de diferentes áreas do conhecimento (linguistas e sociólogos, especialmente). Como esses, depois de fundarem o campo, divergiram sobre o quanto de cada área (em termos de teorias e métodos) era necessário para o estudo de fenômenos sociais e linguísticos, especializaram o campo em dois polos: a macrossociolinguística, que recobre diferentes vertentes, como a sociologia da linguagem, a etnografia da fala e a abordagem interacional; e a microssociolinguística, que recobre a sociolinguística variacionista. (cf. SHUY, 2003).
} 
- Breve percurso histórico de abordagens linguísticas que antecedem e influenciam a constituição da sociolinguística variacionista

Em linhas gerais, essa prática de pesquisa, admitindo que a língua que serve a uma comunidade real, sempre complexa, deve ser igualmente complexa, concebeu língua como um sistema heterogêneo, variável, embora estruturado, ou seja, sistemático, uma vez que a heterogeneidade é motivada por um conjunto de fatores correlacionados, que são tanto de natureza linguística quanto de natureza extralinguística.

Como toda mudança implica variabilidade e heterogeneidade, embora nem toda variação resulte em mudança linguística (WLH, 2006 [1968]), a SV, justamente com vistas à explicação da mudança linguística, se voltou para a variação, já que é pela compreensão dessa que se chega a previsões quanto a possíveis mudanças linguísticas.

Uma vez que a variação é sistemática, motivada por múltiplas causas e que há "ampla evidência de que a competência linguística humana inclui restrições quantitativas" (LABOV, 1978, p. 13), trabalha-se, na SV, com o pressuposto de que a variação pode ser modelada quantitativamente, por meio de técnicas estatísticas de análises multivariadas, que permitem: (i) identificar fatores significativos para a variação; (ii) organizá-los qualitativamente, tendo em vista a ordem de relevância para a variação bem como a interrelação entre os diversos fatores; (iii) refletir sobre a direção da mudança, tendo em vista os princípios teóricos do campo. Em termos metodológicos, a SV é, portanto, descritivointerpretativa (GUY; ZILLES, 2007; TAGLIAMONTE, 2012; BRAGANÇA, 2017).

Bragança (2017), sistematizando uma versão ${ }^{22}$ sobre a gênese dos estudos variacionistas, destaca as seguintes influências históricas na constituição da SV:

a) Whitney, que influenciou Saussure, no que tange à concepção de língua como fato social (aqui, afastando-se da tradição neogramática que via a língua como um fenômeno de natureza psicológica);

b) Meillet (aluno de Saussure), que levou a cabo com mais radicalidade a noção de língua como fato social, e passou a convocar aspectos sociais para a explicação linguística, aproximando-se, assim, de estudos antropológicos e sociológicos (de Durkheim, especialmente);

c) Martinet (aluno de Meillet), tratou a mudança linguística como um fenômeno sistêmico (e não isolado) e realizou estudo dialetológico com foco na compreensão de usos linguísticos que distinguiam pequenos grupos, quando o cerne dos estudos dialetológicos eram questões macroculturais;

22 Porque a historiografia da sociolinguística ainda carece de estudos mais aprofundados. Cf. Koerner (1991). 
d) Martinet orientou Weinreich ${ }^{23}$ em um estudo geográfico do bilinguismo, em sua tese de doutorado;

e) E Weinreich orientou Labov, o fundador da SV, em seus trabalhos de mestrado e doutorado.

Nas palavras de Bragança (2017, p. 205):

Essa linha histórica das relações entre os pesquisadores faz ver, simplificadamente, o modo como concepções de diferentes campos e de diferentes linguistas chegaram até Labov, fazendo com que o tema da mudança linguística, cerne dos estudos do século XIX e preocupação "eliminada do programa da linguística do século XX" (LABOV, 2008 [1972] , p. 14), renascesse de forma renovada, na segunda metade do século XX, ao se conciliar "vertentes de pesquisa linguística, geográfica e antropológica (com sensível viés etnográfico)" (CAVALIERE, 2014, p. 613).

Ademais, a pesquisadora ainda aponta as seguintes influências na SV:

a) Dos neogramáticos: a compreensão de que a mudança é regular;

b) Do estruturalismo: a noção de língua como sistema abstrato;

c) Do gerativismo: a concepção formal de língua (língua como sistema de regras subjacentes; mas, em vez de regra opcional, regra variável);

d) Dos estudos dialetológicos (norte-americanos): a prática etnográfica de se descrever (i) línguas contemporâneas de áreas geográficas específicas, como centros urbanos, e (ii) falantes de diferentes níveis sociais ${ }^{24}$, com as seguintes modificações: no método da dialetologia, no tratamento dos elementos do sistema linguístico (vistos como partes de um sistema), no modo de compreender a relação entre sincronia e diacronia.

Por essa breve revisão, pode-se questionar até que ponto a SV, inscrita em um campo que nasce com o desejo de se afastar do formalismo linguístico, ao se dedicar à relação entre linguagem e sociedade, atinge, de fato, seus objetivos. Nas palavras de

23 Por questões de espaço, não exploramos com mais detalhes a vida e a produção de Weinreich. Para mais informações sobre isso, cf. Marra e Milani (2011).

24 Cf. os estudos de Martha's Vineyard (1963) e de Nova York (1966), de Labov, que inauguram as investigações variacionistas. 
- Breve percurso histórico de abordagens linguísticas que antecedem e influenciam a constituição da sociolinguística variacionista

Camacho (2013, p. 100), a SV ainda "harmoniza os fatores empíricos da heterogeneidade com o procedimento epistemológico de uma abordagem estrutural".

Sintomático é, pois, o fato de a SV, desde sua constituição, ter passado por sucessivas revisões, a ponto de haver, atualmente, uma terceira onda variacionista (cf. ECKERT, 2012), de natureza discursiva (cf. BRAGANÇA, 2017), e, por isso, mesmo ainda em fase de compreensão, por parte da comunidade acadêmica. Ao que parece, essa onda sim rompe com preceitos formalistas, uma vez que "[...] no movimento da primeira para a terceira onda de estudos de variação, toda visão da relação entre linguagem e sociedade foi modificada [...] com consequências potencialmente importantes para a teoria linguística em geral" (ECKERT, 2012, p. 97-98).

O que seria essa terceira onda variacionista, quais são suas influências históricas e como os temas variação e mudança linguística são (re)tratados sob essa nova epistemologia são alguns temas de trabalho a serem enfrentados pelos pesquisadores variacionistas. Em diferentes frentes de trabalho, a tarefa dos analistas agora parece ser, dada a tensão epistemológica entre primeira e terceira fase da SV, produzir conhecimento sobre a seguinte questão:

[...] quanto do que acorre com a língua, em termos de variação e mudança, é resultado do trabalho social de seus usuários a partir da identidade social específica de que são dotados ou o resultado de padrões formais, estruturais, que regem, por si sós, os processos de estabilidade e mudança [?] (CAMACHO, 2013, p. 21).

\section{Agradecimentos}

Agradeço aos pareceristas pelas contribuições. As faltas encontradas neste texto são de minha responsabilidade.

\section{Referências}

BRAGANÇA, M. L. L. Uma proposta de articulação teórico-metodológica entre os campos variacionista, funcionalista e dialógico para o tratamento de variação/ mudança: reflexões a partir da expressão do futuro do presente. 2017. Tese (Doutorado em Linguística) - Centro de Comunicação e Expressão, Universidade Federal de Santa Catarina, Florianópolis, 2017. 
CAMACHO, R. G. Da linguística formal à linguística social. São Paulo: Parábola, 2013.

CÂMARA Jr., J. M. História da linguística. Tradução Maria do Amparo Barbosa de Azevedo. 7. ed. Petrópolis: Vozes, 2011.

CAVALIERE, R. Vertentes da sociolinguística no Brasil. Web-Revista SOCIODIALETO, v. 4, n. 12, p. 612-624, 2014.

COSTA, L. C. S. Saussure: entre o poder acadêmico e a saber científico. 2015. Tese (Doutorado em Linguística) - Centro de Comunicação e Expressão, Universidade Federal de Santa Catarina, Florianópolis, 2015.

ECKERT, P. Three waves of variation study: The emergence of meaning in the study of variation. Annual Review of Anthropology, n. 41, p. 87-100, jun. 2012.

FARACO, C. A. Linguística histórica: uma introdução ao estudo da história das línguas. São Paulo: Parábola Editorial, 2005.

FIGUEROA, E. Sociolinguistic metatheory. Oxford: Pergamon, 1994.

GERALDI, J. W. Portos de passagem. São Paulo: Martins Fontes, 1990.

GUY, G. R.; ZILLES, A. M. Sociolinguística quantitativa: instrumental de análise. São Paulo: Parábola, 2007.

KOERNER, K. William Labov e as origens da sociolinguística na América. In: KOERNER, K. Quatro décadas de historiografia linguística: estudos selecionados. Seleção de Textos de Rolf Kemmler e Cristina Altman. Organização de Carlos Assunção. Vila Real: Universidade de Trás-Os-Montes e Alto Douro, 2014. p. 117-138.

LABOV, W. Where does the linguistic variable stop? A response to Beatriz Lavandera. Working Papers in Sociolinguistics, v. 44, abr. 1978.

LE PAGE, R. B. The Evolution of a Sociolinguistic Theory of Language. In: COULMAS, F. (ed.). The Handbook of Sociolinguistics. Blackwell Publishing, 1998. Disponível em: http://pt.bookzz.org/book/963370/1ef2e1. Acesso em: 21 ago. 2016. 
- Breve percurso histórico de abordagens linguísticas que antecedem e influenciam a constituição da sociolinguística variacionista

LYONS, J. Introdução à linguística teórica. Tradução Rosa Virgínia Mattos e Silva e Hélio Pimentel. v. 13. São Paulo: Companhia Editora Nacional da Universidade de São Paulo, 1979.

LYONS, J. Linguagem e Linguística: uma introdução. Tradução Marilda W. Averbug e Clarisse S. de Souza. Rio de Janeiro: LTC - Livros Técnicos e Científicos Editora S.A, 1981.

MARRA, D.; MILANI, S. E. A gênese historiográfica linguístico-científica de Labov. Revista Linha D'Água, v. 24, p. 139, 2011.

MILANI, S. E. Historiografia dos estudos de Willian D. Whitney: a lei do menor esforço. Linha d'Agua, v. 20, p. 37-47, 2007.

MILROY, L.; GORDON, M. Sociolinguistics - Method and Interpretation. Oxford: Blackwell, 2003.

ROBINS, R. H. Pequena História da Linguística. Tradução Luiz Martins Monteiro de Barros. Rio de Janeiro: Ao Livro Técnico, 1983.

SAUSSURE, F. de. Curso de Linguística Geral. Tradução Antônio Chelini, José Paes e Izidoro Blikstein. 27. ed. São Paulo: Cultrix, 2006 [1916].

SEVERO, C. G. Humboldt e a relação entre linguagem, ser humano e mundo: uma visão holística. Linguasagem, São Paulo, v. 2, p. 01-08, 2008.

SHUY, R. W. A brief history of American Sociolinguistics 1949-1989. In: PAULSTON, C. B.; TUCKER, G. R. (ed.). Sociolinguistics: the essential readings. Malden: Blackwell Publishing, 2003. p. 4-16.

TAGLIAMONTE, S. A. Variationist sociolinguistics: change, observation, interpretation. Cambridge: Wiley - Blackwell, 2012.

WEINREICH, U.; LABOV, W.; HERZOG, M. Fundamentos empíricos para uma teoria da mudança linguística. São Paulo: Parábola, 2006 [1968]. 
- Breve percurso histórico de abordagens linguísticas que antecedem e influenciam a constituição da sociolinguística variacionista

COMO CITAR ESTE ARTIGO: LACERDA, Marcela Langa. Breve percurso histórico de abordagens linguísticas que antecedem e influenciam a constituição da sociolinguística variacionista. Revista do GEL, v. 18, n. 1, p. 68-100, 2021. Disponível em: https://revistadogel.gel.org.br/

Submetido em: 28/12/2020 | Aceito em: 23/01/2021. 